\title{
PERCEPTION OF THE Z GENERATION REGARDING THE PROMOTION WAY OF ROMANIAN ARMY INSTITUTION
}

\author{
Robert Georgian RIPICEANU \\ "Nicolae Bălcescu" Land Forces Academy, Sibiu, Romania \\ ripiceanu.robert@gmail.com
}

\begin{abstract}
This article approaches the attitude of $Z$ Generation concerning the promoting of the Romanian Army Institution in social media. This domain is a rigorous one, based on serosity and there are not a multitude of common values with this generation. Technology is a world-known aspect and the IGeneration is known as being born with new technological culture and they do not require to adjust to it. They prefer socializing in online, capture some meaningful general knowledge from their intercommunications. The Internet proposes various techniques of enticing youngsters to consume a lot of time online, on their smart devices.
\end{abstract}

KEYWORDS: army institution, romanian army, social media, Z generation

\section{Introduction}

We live in a progressive world and technology is omnipresent, day by day. Perceptions shape among generations. The external social influence becomes an important discussion, which we want to point out. Even if we talk about the mass-media or about the impact of groups we take part in, beliefs are developed on some pillars.

This article is designed around the opportunities the new generation attends public interest information and what they think about the necessity for sustaining a state institution. The study started from a personal admiration for the army, interest in advertising and social media field.

There are established three research questions:

1. Which are the modalities through which the Romanian Army use social media for promoting itself?

2. What teenagers from $Z$ Generation reflect about this Institution?
3. Which platforms, from Facebook and Instagram, appear more impressive for this generation?

This article starts from the assumption that teenagers from $Z$ Generation are less involved and less interested in the Army field and the way of improving it in social media would destroy some stereotypes and also, would improve the communicational level with the audience. For presenting this state, were used two research methods, content analysis, and the public opinion poll.

The $\mathrm{Z}$ Generation is concerned about 1996 to 2009. There are similarities between the millennials and this generation. If before the $\mathrm{Z}$ generation, the Internet was something not so popular, rarely used, for IGeneration this is a reality they are born with. Technology is the central element this generation is surrounded by. Social media, networking, digital interactions, all these are regularly used by this generation. We should 
observe that generation trends change quickly, we become addicted and they mark us as a group (Özkan \& Solmaz 2017).

\section{Romanian Army and its Values}

The state represents the ensemble of political, military and administrative institutions of a nation (Joseph, 1973, p.125). The Army is of them. It is portrayed by the force of crowd, whereby are used defence services of a country. Essentially, the Army contribution consists in defending the territory, to guarantee the statehood, to protect and help the citizens. (Duţu, Moștoflei \& Dolghin, 2005).

Regarding the content, the rapport army- society can be collaboration, communication, leadership, knowledge, indifference, badness, influence. All these reports are a coherent ensemble, whereby elements are interactions. (Duțu, Moștoflei \& Dolghin, 2005).

The Army, as a state institution, is defined by some important elements:

1. Firstly, is a social component. It represents the social structure and the state force.

2. It has an actional autonomy. As a military institution, through its way of systemization, the quality of its military group, through its technical equipment, it can accomplish military missions.

3. The purpose is the legal use of violence. By peace times, the army does not have the fight as a work item and it exists humane actions, peacekeeping missions.

4. The capacity to resist difficult conditions.

5. It is very structured.

6. It has a fast evolution.

Based on these characteristics, we can say that, nowadays, we face a new tendency, of passing from a mobile military force to a permanent one (Sava, Zulean, \& Tibil, 1998, pp. 10-18). The social functions which the Army has in the society represent another important component (Duţu, 2002, pp. 24-28).
Teenagers are prepared for their life. The Army teaches people how to be wellschooled, how to respect rules and activities specific to military life.

a. It carries traditional values to youths. The educative-instructive activities they take part during their stay in the military service, but also in the fight missions encourage them to assimilate traditional values, as honour, the proud to be Romanian, loyalty, which they might transmit further in the community.

b. It contributes to socializing and maturation.

All these socio-cultural elements form an opinion or add ideas to already formed opinions about the Romanian Army. Accomplishing these social functions, they directly act on the qualitative content on defending mission on the national territory.

3. The Mass-Media Role in Defining Opinions

Through history, it survived and also remodelled a lot of mass media types. The messages may transform the culture, behaviour, beliefs and the actions a person, a group, an organization or an institution possess. The culture and the media are influencing one to another in different ways (McFadden, 2010, pp. 25-56).

Four of the most important media qualities are:

a. It promotes a ludic spirit, good for the creativity

b. It educates and informs people

c. It examines major problems

d. It accomplishes a defending function for institutions, governments, businesses

The population and their perspectives are different from a generation to another. In this article, we will analyse the principal aspects of generation $\mathrm{Z}$. Some studies show that is 2.1 million Internet users globally, and $82 \%$ of these are above 15 years old and use social media daily. These generation, named also Igen, giving the fact they are born during the iPhone era, are the 
ones who will revolutionize the future. They spent a lot of time online, on the most known platform as Instagram or Facebook.

Social media fundamentally shaped the way people communicate, create, consume or interact. Its dynamics is a unique characteristic. Through social media, we can refer to information sharing, experiences, photos and perspectives. For example, blogs, video blogs, podcasts, and other online groups facilitate communication between people, having an impact on virtual possibilities and needs (Weinberg, 2009, p. 1).

Here are presented some data, referring to the number of social media users in Romania. There are 13.74 million Internet users, 10 million daily use social media, and other 9 million use it from their mobile phones, from about 19.63 population (We Are Social, Hootsuite, 2018).

\section{Methodological Frame}

The content analysis and the opinion poll are the methods used in this research. The first one emphasizes the details Romanian Army Institution use for promoting on Instagram and Facebook, what hashtags they use, and what is the "likes" number for photos on the February June period of 2016-2018. In February 2016, The Romanian Army posted their first photo on Instagram and I looked on this period of time because there are both some national days, but also important events in the military domain. I wanted to see how those moments would be promoted on social media and what impact whould have, comparing the beginning period of Instagram for this Institution and the next two years. We also looked at how frequent they post, how are the comments and what is the audience reaction about the photos. Romanian Army Instagram's Page releases both professional photos but also from the archive or received by other Institution's workers. Important to notice is the fact that most of the photos are provided the source. We noted that the Romanian Army does not use all resources Instagram provides; for instance InstaStories, besides the video content is reserved.

We find frequent posts, once every 1 or 2 days, sometimes even 2 posts per day. Rarely we found a large variation, of a maximum 5 days between posts. But when this occurred, the next few days existed an adjustment and regular posting stream. On Instagram, the total number of likes raised surprisingly in 2018, if we compare with previous years.

The Instagram page includes photos from missions and intern activities. They prefer to enlarge citizens' engagement and bring in the foreground emotional photos where soldiers can be seen with their families or in the society, from different civic missions. Most of them show significant military daily life moment. The main themes the Romanian Army promotes on Instagram refers to family, the civic space, patriotism, intern and extern missions.

The second method, the survey, was made on 70 adolescents from 15 to 18 years old, having an urban background. The survey includes the following aims: to identify teenagers' preferences regarding social media platforms, defining the time spent in social media, distinguishing content preferences of social media platforms, motivating opinions regarding the idea of promoting the Army Institutions in social media, evaluating the interest for the Institution. The distribution by gender included in the survey is represented by 40 girls $(57 \%)$ and 30 boys (43\%). The questionnaire contains 17 questions, directed from general to particular, meaning 10 closed questions, with 3,4 or 5 answer options and also 5 open questions. We required the respondents to be truthful and formulate their individual feelings and motivate them. The main advantage of open questions is they operate with qualitative 
data, even if some responses may not be so extended or there may be gaps in expressing your personal opinion.

\section{Results}

People from Gen $Z$ prefers the Instagram account of the Romanian Army instead of the Facebook one, thanks to the multiple functions as "stories" and the dynamic way photos are shared. So, 38 of the people surveyed said they use Instagram, while just 18 people spend more time on Facebook. Also, 11 teenagers sustain they prefer more other platforms, like Snapchat, Pinterest or Twitter.

It is remarked considerable more interest of teenagers and positive comments, also the best quality of the content. Facebook is a little bit too much crowded with posts from all kind of activities, not very structured, but they appreciate the way the Romanian Army promotes on the Internet.

Most teenagers (44\%) think the promoting in social media is important, 3 people consider it useless, one person less important and 29 of them (41\%) believe it is not the most important thing, but it should not be missing out, so had an impartial perspective. Just 7 people think it is the key to good communication with the audience.

On the question "On a scale from 1 to 5, where 1 means Not At All, and 5 Means Very much, how interested do you think are other people from your age regarding the Army Institution in social media? " I wanted to verify if surveyed people consider a specific behaviour characteristic for their age would be addressed to other people from the same generation. And 47 adolescents consider that other teenagers are still uninterested in this field, 9- "less interested", 11 said "much" and 2 "very much" and just a single person thinks other people from the same age are not interested at all.
Considering the online part is a good method for promoting tis Institution, we asked the teenagers what they think about it. Twenty of them said that social media is a safe method through which teenagers may become interested in this field, three do not consider it a good way and the majority 46 people - think that social media is a strategy for attracting adolescents for a future military career.

\section{Conclusions}

Based on the research, we could say that the Romanian Army use new socializing media functions, which a large population number also prefer. The Army Institution use posts in order to get in touch with the audience, maintaining a good contact with them, posting photos from intern activities and also extern missions. Despite these daily activities that maintain contact with people, the Institution prefer to enlarge the audience's interest by giving examples of emotional photos, from the personal lives of soldiers, with their families or simply in the middle of a social or cultural position. Therefore, in social media, the Romanian Army does not imply only on the intern part of the Institution but emphasizes the daily parts of military life, with the ups and downs.

This research points out the fact that teenagers from $\mathrm{Z}$ Generation are not very interested in this field, of Army. They think about military jobs being too risky or difficult. Even if they know information only from the media or from their families or friends, they respect the domain and the hardness of the profession. They morally sustain the activities, which are partly difficult and hard to execute, and they consider "heroes" people who are part of this field and Institution.

Regarding the social media part, Instagram leads by far in this social media competition. Teenagers are attracted by the dynamic and complex way of the platform, they prefer the posts possibilities, hashtags 
and the huge number of same age people, who also use this platform.

Another essential aspect observed by people born after 2000 is the patriotism and the respect which is showed through the posts. They admit that are not very interested in following a career in the Army, but they appreciate the effort and the spirit that the Army's employees offer to the country, every single day. The promotion on social media attracts some teenagers in a future career, maybe because of the family' suggestions or simply for their institution's appreciation.

In conclusion, promoting on social media might have a significant impact on the population, especially for the youngers. They spend a lot of time online and prefer to analyze and develop an interest in their needs. They think the Romanian Army it is essential to be visible through people, to show the main activities, to commemorate and spread news from missions.

\section{REFERENCES}

Duțu, P. (2002). Armata şi societatea în tranziţie. Bucureşti: Editura Academiei de Înalte Studii Militare.

Duțu, P., Moștoflei, C., \& Dolghin, N. (2005). Raporturile dintre armată şi societate în procesul integrării europene şi Euro-Atlantice a României. Universitatea Naţională de Apărare „Carol I” - Centrul de Studii Strategice de Apărare şi Securitate, 21.

Joseph, S. M. (1973). Dictionnaire de sociologie. Paris: Larousse.

McFadden, J. B. (2010). Understanding Media and Culture: An Introduction to Mass Communication. Minneapolis: University of Minnesota Libraries.

Özkan, M., \& Solmaz, B. (2017). Generation Z - The Global Market's New Consumers And Their Consumption Habits: Generation Z Consumption Scale. European Journal of Multidisciplinary Studies, Vol. 2, Issue 5, available at: http://journals.euser.org.

Sava, I. N., Zulean, M., \& Tibil, Ghe. (1998). Armata și Societatea (Culegere de texte de Socilologie Militară). București: Info-Team.

We Are Social Ltd, Hootsuite. (2018). DIGITAL YEARBOOK headline internet, social media, and mobile use data for every country in the world, available at: https://wearesocial.com/blog/2018/01/global-digital-report-2018.

Weinberg, T. (2009). The New Community Rules: Marketing on the Social Web. Gravenstein Highway North, Sebastopol, CA: O’Reilly Media. 